\title{
Deep-water fossorial shrimps from the Oligocene Kiscell Clay of Hungary: Taxonomy and palaeoecology
}

\author{
Matúš Hyžný and Alfréd Dulai \\ Acta Palaeontologica Polonica 59 (4), 2014: 947-965 doi: http://dx.doi.org/10.4202/app.2012.0078
}

We describe deep-water ghost shrimp assemblages from the otherwise well known Oligocene Kiscell Clay in Hungary. The described fossorial shrimps (Decapoda:

Callianassidae and Ctenochelidae) include: Ctenocheles rupeliensis (younger synonym Callianassa nuda ) and Lepidophthalmus crateriferus (younger synonym Callianassa brevimanus). The fossil material of the former species is assigned to Ctenocheles based on the morphology of the major cheliped, particularly the pectinate fingers, bulbous propodus, cup-shaped carpus and elongated merus. Lepidophthalmus crateriferus from the Oligocene of Hungary is the first unequivocal fossil record of the genus, which is distinguished in the fossil record on the basis of the presence of a meral blade and meral hook on the major cheliped. Lepidophthalmus is today known exclusively from shallow-water environments. The finding of a deep-water fossil representative of Lepidophthalmus therefore appears to be a reverse of the common pattern of groups shifting environments from onshore to offshore over geological time, as seen in many taxa. The presence of Lepidophthalmus crateriferus comb. nov. in the Kiscell Clay therefore suggests different ecological requirements for at least some populations of this genus in the geological past.

Key words: Decapoda, Callianassidae, Lepidophthalmus, Ctenochelidae, Ctenocheles, systematics, deep-water environment, Oligocene, Hungary.

Matúš Hyžný [hyzny.matus@gmail.com], Department of Geology and Palaeontology, Faculty of Natural Sciences, Comenius University, Mlynská dolina G1, Bratislava 842 15, Slovakia; Alfréd Dulai [dulai@nhmus.hu], Department of Palaeontology and Geology, Hungarian Natural History Museum, Ludovika tér 2, Budapest H-1088, Hungary; (Postal address: H-1431, Budapest, P.O.B. 137).

This is an open-access article distributed under the terms of the Creative Commons 
Attribution License (for details please see creativecommons.org), which permits unrestricted use, distribution, and reproduction in any medium, provided the original author and source are credited.

PoFif Full text $(987.4 \mathrm{kB})$ 